ISSN 2449-7479

eISSN 2543-8840

amme.wne.sggw.pl

\author{
Annals of Marketing Management \& Economics \\ Vol. 4, No 1, 2018, 101-113 \\ DOI 10.22630/AMME.2018.4.1.8
}

\title{
INSTAGRAM AS A TOOL FOR PROMOTING SUPERFOOD PRODUCTS
}

\author{
Anna Roth, Tomasz Zawadzki \\ Poznań University of Economics and Business, Poland
}

\section{INTRODUCTION}

Intensification of online communication is an ever-growing trend in buyers. A significant part of the society uses the Internet as a source of information, entertainment or as a way to stay in touch with their family, friends as well as strangers. This willingness to exchange opinions on all kinds of issues has encouraged companies to contribute to the flow of information in social media. Taking advantage of a number of social networking websites, a business can interact with its target group. In this way, both sides can profit from direct and immediate feedback. Enterprises do their best to make good use of the available tools in order to convert random Internet users into actual clients purchasing their products. Social media have become a good solution for companies to promote new products with their sometimes very particular characteristics. An example of such a product is superfood, a category of products which is expanding rapidly and therefore needs new ways of reaching its consumers. A channel often used for this purpose is Instagram, a social networking website which utilises the structure of its content - very big, attractive photographs - to present products in a favourable way and influence the shopping decisions of the recipients of a brand's message.

\section{THE ROLE OF SOCIAL MEDIA}

Nowadays companies compete for the attention of consumers on many levels. One that is developing dynamically is their participation in direct interaction with Internet communities. Social media make it possible and their number is constantly growing. 
Using social media for promoting a business and its product is known as social marketing. It is sometimes defined as a form of viral marketing due to the fact that it consists of passing content to other users, for example by recommending specific products and services or by discouraging other people from buying them [Barefoot and Szabo 2011]. In order to remain highly competitive, an enterprise needs to continue to adjust its communications strategies to the current and ever-changing expectations of consumers. This is particularly significant for small and medium-sized companies as they run on a limited budget and look for solutions that translate directly into sales figures.

Social networks make it possible to engage in non-anonymous conversations with friends on a variety of topics, including those connected with brands. Consumers interact with social media profiles of enterprises by writing posts, reading the posts of other users and brands, posting comments, liking things or doing the equivalent depending on the medium, forwarding or sharing content and engaging in a number of similar activities available within such channels. Increasing involvement of consumers influences the visibility of a brand and the spreading of information about it (word-of-mouth marketing). Internet users are happy to share their opinions and experiences in social media, which opens up a window of possibility for companies to take advantage of this form of communication [Erkan 2015]. Social media are usually defined as media intended to facilitate interaction between users [Hassan 2014].

Prior to the development of social media, companies used to rely on one-way online communication by using tools such as banners, pop-ups or sponsored advertisements. This has since transformed into two-way communication between the brand and the consumer. The communication may assume the form of involvement at the stage of shaping the final product and choosing the preferred channels of distribution or at the stage of negotiating the quality of the offer via various forms of feedback [Hassan 2014]. Figuring out the right marketing strategy for a company has an influence on successful fulfilment of the intended aims in terms of the company's image or communications policy. The effects of such activity include:

- increase in brand visibility on the Internet,

- improved brand recognition among potential consumers,

- increased number of unique users of the brand's website,

- increased number of photos displayed and videos played in hosting services,

- increased number of online opinions on the company's offer,

- improvement in result positioning in Google's ranking algorithm,

- increase in sales figures for the brand's products or services.

Proactive behaviour in social media may have significant influence on the conversion of potential consumers into actual clients of the enterprise [Barefoot and Szabo].

Entrepreneurs perceive social media as a channel facilitating interaction between consumers and the brand on the Internet in real time. Users can get acquainted with products and services and provide their feedback on the enterprise. Using social media, brands are able to respond to potential problems of their customers more quickly, which greatly increases their satisfaction levels. Measured online communications policy is an effective way to spread positive recommendations and opinions about the enterprise. Compared with traditional media, the cost of reaching out to a significant number of recipients is relatively low, a fact which contributes to the high popularity of this type of communication [Momany and Alshboul 2016]. 
The dynamic increase of the share of mobile devices in browsing the Internet has become more and more visible in recent years. $66 \%$ of the world population currently owns a mobile phone and as many as 2.5 billion people use the device to access social media (34\%). In comparison with last year (January 2017 vs. January 2016) the figure increased by $30 \%$. An important factor here might also be the spreading of the share of particular devices in terms of accessing online services (Internet traffic), with 50\% of the worldwide share assumed by mobile devices. For Poland, the figure is as high as 57\% [We are social 2017]. The conclusion is that the potential of mobile users is ever on the rise and causes social media communications channels dedicated for the group to become more and more interesting for enterprises. A particular Internet service of this sort is Instagram, the characteristics of which are esteemed highly by consumers interested in mobility and new technologies. Its popularity has soared in the recent years.

The social networking website Instagram consists of profiles which users and brands use to post photos or videos with short descriptions and often at least one hashtag (a key word relating to the contents of the message, preceded by the symbol \#). Users can also make use of built-in filters to edit a photo before they publish it. A basic indicator of the efficiency of communication on Instagram is the number of likes and comments under the content posted on the user's or company's profile. Research to date has shown that indicators of consumer involvement on business profiles may be dependent on the line of business [Erkan 2015]. Table 1 presents classification of users on the social networking website. It differentiates between 5 basic types, making it easier to choose a target group for a given brand's communication. The greatest number of potential clients can been found in the group of readers [Garifova 2016].

TABLE 1. Classification of users on the social networking website Instagram

\begin{tabular}{|l|l|}
\hline Group & \multicolumn{1}{c|}{ Description } \\
\hline $\begin{array}{l}\text { Small enterprises, } \\
\text { shops and services }\end{array}$ & $\begin{array}{l}\text { Refers to specific industries, among others sport, food, health, animals, pho- } \\
\text { tography, weddings, holidays, clothes, cosmetics, education, handicraft. }\end{array}$ \\
\hline Hobbies & $\begin{array}{l}\text { A profile created in relation to a user's hobby or on account of potential } \\
\text { income for the user (selling advertisements, organising campaigns on the } \\
\text { profile). }\end{array}$ \\
\hline Stars & $\begin{array}{l}\text { Famous people posting their own photos. They typically follow few other } \\
\text { users themselves, but have a huge number of followers (more than 100,000 } \\
\text { users). They are not potential clients, but they present an opportunity for } \\
\text { brands to promote their products or services among the followers of a given } \\
\text { famous person. }\end{array}$ \\
\hline $\begin{array}{l}\text { Celebrities, } \\
\text { bloggers }\end{array}$ & $\begin{array}{l}\text { People known to a lesser extent, usually popular within a specific thema- } \\
\text { tic community. They are followed by between 10,000 and 100,000 people. } \\
\text { Just like with the category above, they do not constitute potential clients, } \\
\text { but they give brands an opportunity for promotion of products and services } \\
\text { among followers. }\end{array}$ \\
\hline Readers & $\begin{array}{l}\text { Different users, among others travellers, tourists, young mothers, dog or cat } \\
\text { lovers, amateur athletes. They have between 10,000 and 100,000 followers, } \\
\text { and they follow about 1,000 profiles themselves. }\end{array}$ \\
\hline Source: [Garifova 2016].
\end{tabular}




\section{SOCIAL MEDIA AS AN EFFICIENT CHANNEL FOR MARKETING COMMUNICATIONS}

Social media have a direct impact on the way consumers perceive a brand. Brand image in the eyes of consumers can be shaped by means of interactive communication of the brand's features and values. Skilful use of social media maximises consumer engagement and creates a personalised relation between the consumer and the brand, a relation sometimes seen as private. This can result in a growth of the number of fans, likes and comments [Hassan 2014].

As we analyse social media, we need to pay special attention to the issue of sales and sales promotion. Before the technological revolution took place, enterprises had reached their customers through traditional channels of communication. Nowadays the Internet is used for that purpose more and more frequently. This change follows from the evolving behavioural patterns of buyers, many of whom have started to see the Internet as their preferred channel of communication. Social media initially shot to popularity as places where Internet users could socialise with other people. Brands, however, noticed the potential of social media but used it as a way to reach their customers [Hassan 2014]. Due to the evolution of communication - which more and more often assumes the form of a dialogue between the consumer and the brand - the way that social media are being used is undergoing a similar transformation. Consumers are becoming more and more demanding and brands have no choice but to meet their requirements. Methods of promotion that were effective at the beginning of the development of social media cannot deliver the same kind of satisfactory results anymore, which forces brands to work out new methods to influence the behaviour of buyers.

Due to the growing popularity of brands communicating via social media, research is being conducted to determine the exact relation between the so-called firm-generated content and what consumers actually purchase, also with respect to the long-term interaction between the consumer and the brand. This way, the viability of specific activities of enterprises can be verified. What concerns the spendings of a consumer - seen here as his or her transactional value for an enterprise - the impact of the content is determined in reference to the brand's sales figures. On the other hand, buying additional products, defined as the number of different product categories within which the consumer purchases anything specifies the intensity of the relation between the consumer and the brand. Direct correlation between these indicators has been discovered, which implies that it makes sense to conduct such research in social media. Enterprises ought to engage in communication with consumers and build long-term relations that result in profit from the sales of products and services [Kumar et al. 2016].

According to Table 2, research conducted on 22,618 Internet users has indicated that the behaviour of online buyers is mainly shaped by opinions of other Internet users, by the possibility to take advantage of special offers as well as by various advertising formats [PricewaterhouseCoopers 2016]. Because of the specificity of Instagram - it is oriented towards visual communication - many Internet users refer to it for product information and for inspiration.

Because the above factors affect the behaviour of consumers, the phenomenon of social selling is developing rapidly. Social selling is understood as all the activity of an 
TABLE 2. Aspects of social media which influence the shopping patterns of online consumers (September 2015)

\begin{tabular}{|l|c|}
\hline Aspect & Share of the response [\%] \\
\hline Reading opinions, comments and feedback & 45 \\
\hline Access to special offers & 44 \\
\hline Browsing advertisements & 30 \\
\hline Following trends concerning fashion and products & 25 \\
\hline Writing opinions, comments and feedback & 22 \\
\hline Identifying with a brand or a retailer & 20 \\
\hline Buying products directly via a social networking website & 16 \\
\hline
\end{tabular}

Source: PricewaterhouseCoopers 2016.

enterprise in social media that brings about an increase in sales possibilities. The starting point for such activity is creating brand profiles on selected social networking websites and deciding on a communications policy that would be adjusted to the target group. Typical strategies of a brand's presence in social media include building long-term relations through finely polished content (content marketing) and getting involved in discussions concerning issues closely related to the brand's offer [Gumińska 2017].

Instagram is especially efficient with respect to $\mathrm{B} 2 \mathrm{C}$ communication (business-to-customer). The decision-making process is influenced to a great extent by the appearance of the product or the place where the services are offered. Instagram makes it easy for a brand to be associated with positive visual communications. The website is equipped with features designed to help convert brand followers into clients. In March 2017 8 million enterprises had profiles on the website and out of these an average of 1 million advertised their products or services in an active way every month (an increase by some 800,000 profiles in comparison with March 2016). Business profiles were followed by over $80 \%$ of the users of the website, and as for the users themselves in March 2017 their number amounted to over 600 million people. According to the official data provided by Instagram, in February 2017 as many as 120 million people used the website to visit a company's website, to get directions to a company or their contact data. This proves that more and more companies discover the potential of the website and that users treat Instagram as a source of information about companies [Instagram 2017b]. Moreover, as many as $49 \%$ of users search Instagram for interesting brands while $14 \%$ of users declare themselves potentially interested in clicking on the "Shop Now" button available on the website. These are the highest numbers in comparison with other social networking websites (e.g. 39 and 9\% respectively for Facebook). In order to further improve the efficiency of their communication and social selling, enterprises also make use of tools which monitor the contents of the Internet, to be able to respond to the activities of the target group in the shortest time possible [Karwat 2016].

The possibility of tagging products in content posted via business profiles is currently being tested. When they browse posts, users can easily distinguish the ones relating to products as they bear a special icon placed in the bottom left corner that tells them to touch the photo to display it. Users interested in a product can click on its image to get 
acquainted with basic information about it as well as the price in the form of a pop-up window appearing on top of the photo. When a user clicks on the information window, he is taken to a website which is dedicated to the product but which is still within Instagram. A user interested in the product can choose the "Shop Now" option at the bottom of the page and go directly to an online store, thus greatly shortening his or her shopping path. The maximum number of products an enterprise can tag in a photo is 5 [Instagram 2016]. The new feature has been embraced both by entrepreneurs and users who have been using it a lot. A feature soon to be made available is statistical data to measure precisely the number of clicks on products and on the "Shop Now" button [Instagram 2017a].

\section{ANALYSIS OF BRAND ACTIVITY ON THE SOCIAL NETWORKING WEBSITE INSTAGRAM AS EXEMPLIFIED BY SUPERFOOD PRODUCTS}

Superfood is a term which refers to products containing a wealth of nutritional values, such as Omega-3 fatty acids. "Superfoods are plant products that have been used for centuries all around the world as a remedy for illnesses or as ingredients of bills of fare of local tribes" [Ekiert i Dochnal 2015]. Rock rose, salvia hispanica - chia, spirulina, açaí berries or matzo are just a few examples of superfood products. Thanks to the technological progress, the easier access to information, the relative shortening of the distance between continents as well as the general increase in worldwide wealth there has been a change in eating habits with greater accessibility of products from around the world. Superfood is a key element of a healthy diet as these products have a positive influence on the brain, kidneys, the reproductive system and the metabolism. The effectiveness of superfood in this respect has been proved through numerous scientific research. For example, goji berries are a source of complete protein, they contain polysaccharides which stimulate the immunological system, betaine which cleanses the liver, sesquiterpenes which counter the aging process, antioxidants, over 20 trace minerals and many other [Wolfe 2015].

Nowadays consumers more and more often look for information about products or services on the Internet. The technological progress has granted them with access to a wide range of information at any time. Consumers can familiarise themselves with the offers of enterprises, compare them, get to know the opinion of other Internet users and in the end buy their chosen products online. Internet communication has been affected by the development of social media to a great extent. The change in the way people communicate and its increased interactivity has caused consumers to be more and more proactive in their attitude. Unlike for big corporations, this presents a particular opportunity for small and medium-sized enterprises. While their presence in traditional media is relatively small due to high costs, this can be compensated for by means of staying active in social media, which also allow companies to use less formalised means of communication [Garifova 2016].

In accordance with the above and due to the character of superfood products, which are mostly provided by small and medium-sized enterprises, the conducted analysis of Internet content collected at Instagram has focused on profiles of such enterprises and their brands. People pay more and more attention to their health, they are more aware of their body and its internal correlations. In his publication Philip Kotler mentions an ever 
more important demographic known as LOHAS, or Lifestyles of Health and Sustainability [Kotler and Keller 2012]. They are people who promote a balanced lifestyle (including healthy eating) and personal development. The reports of Nielsen, a research agency seem to confirm that there is a general trend to look after your health, with $77 \%$ of Polish people agreeing with the following saying: "You are what you eat". Indeed, it is health - and not job stability - that is the greatest single worry for Poles [Petrolvenience Raport 2016]. Looking after your health is physical activity on one hand, but on the other it is healthy eating, which can also include superfood products.

For the sake of the present study, the following three representatives of superfood products have been chosen: Chias - liquid snacks with chia seeds, ZmianyZmiany (lit. ChangesChanges) - bars made from fruit and vegetables, PowerWaters - drinks enriched with organic caffeine extracted from green coffee. Table 3 presents the characteristics of the products. They were chosen mostly because they contain elements of superfood, but also because they are available all across Poland, because they use Instagram to promote the image of the brand - and lastly, because they are from Poland (consumer patriotism). The objective of the comparative study is to verify the activity of the brands on Instagram and to identify elements of efficient promotion with respect to these products.

Numerous positive articles on the three products published in specialist magazines confirm that it was reasonable to choose these specific products ${ }^{1}$. Table 4 presents an analysis of the three Instagram profiles.

The Instagram profiles of the analysed enterprises which manufacture products containing elements of superfood are characterised by a similar number of posts and profiles followed. One of the categories used to create Table 4 refers to the rate of engagement, which should be understood as an attempt to describe the combined engagement of all the followers of an Instagram profile. The rate is calculated by adding up the number of likes and comments in relation to the number of followers. The rate seems to be most favourable with respect to the Chias brand, which means that Chias has the greatest proportion of active followers. The majority of posts for all the analysed profiles are product photos - the respective rate is $96.36 \%$ for Chias, $91.7 \%$ for ZmianyZmiany and $87 \%$ for PowerWaters. The policies of the companies are apparently different, however, as regards reposting photos, i.e. posting to your own Instagram profile photos that were previously published by other users of the website (without infringing on anyone's copyrights). This method of posting photos is appreciated by the administrator of the profile@chias_eu, with $73.94 \%$ of photos on the Chias profile reposted from other users, while the figure is as low as 39.5 and 39.1\% for@zmianyzmiany and @powerwaters respectively.

Another interesting piece of data in Table 4 is the relatively high number of Instagram users who tagged Chias products in their own posts. This seems to show high levels of customer satisfaction and identification with the brand. There is a chance that the Chias brand might soon achieve the coveted status of a so-called "lovemark" - a brand enjoying an exceptionally high level of adoration and esteem among its clients. This sort of behaviour among buyers is also a cheap and efficient form of promoting a product. "Information spread with the use of a social networking website travels like a snowball between

\footnotetext{
${ }^{1}$ For example: http://www.portalspozywczy.pl/napoje/wiadomosci/nasiona-chia-w-butelce-tworcymodnej-przekaski-powalcza-o-rynek-z-oshee,128586.html [in Polish], [accessed: 23.03.2017].
} 
TABLE 3. The characteristics of superfood products: Chias, ZmianyZmiany, PowerWaters

\begin{tabular}{|c|c|c|c|}
\hline Specification & Chias & ZmianyZmiany & PowerWaters \\
\hline Type od product & $\begin{array}{l}\text { A liquid snack with } \\
\text { chia seeds and fruit } \\
\text { juices }\end{array}$ & $\begin{array}{l}\text { A plant bar made from } \\
\text { fruit and vegetables }\end{array}$ & $\begin{array}{l}\text { A drink with mineral } \\
\text { water enriched with } \\
\text { organic caffeine }\end{array}$ \\
\hline Producer & $\begin{array}{c}\text { Chias Brothers Europe } \\
\text { Ltd. }\end{array}$ & $\begin{array}{l}\text { ZmianyZmiany (civil } \\
\text { law partnership) }\end{array}$ & Organic Energy Ltd. \\
\hline Number of flavours & 6 & 9 & $\begin{array}{l}1 \text { (another } 2 \text { to be } \\
\text { launched ) }\end{array}$ \\
\hline Superfood ingredient & Chia seeds & Chia seeds, spirulina & $\begin{array}{l}\text { Organic caffeine } \\
\text { extracted from green } \\
\text { coffee }\end{array}$ \\
\hline Places of distribution & $\begin{array}{c}\text { Fitness clubs, health } \\
\text { food stores, petrol } \\
\text { stations (e.g. Lotos), } \\
\text { chain stores (e.g. Piotr } \\
\text { i Pawel) } \\
\end{array}$ & $\begin{array}{l}\text { Fitness clubs, health } \\
\text { food stores, online } \\
\text { stores }\end{array}$ & $\begin{array}{l}\text { Fitness clubs, health } \\
\text { food stores, online } \\
\text { stores }\end{array}$ \\
\hline $\begin{array}{l}\text { Is the product availa- } \\
\text { ble all across Poland? }\end{array}$ & Yes & Yes & Yes \\
\hline $\begin{array}{l}\text { The price of an exam- } \\
\text { ple product from the } \\
\text { product category }\end{array}$ & 5.99 PLN & 6.99 PLN & 3.99 PLN \\
\hline $\begin{array}{l}\text { Ingredients of an } \\
\text { example product from } \\
\text { the product category }\end{array}$ & $\begin{array}{c}\text { Chias pomegranate- } \\
\text {-hibiscus: juice }(66 \%) \\
\text { from concentrate juice } \\
\text { from apples, pine- } \\
\text { apple, pomegranate } \\
(5 \%) \text {, water, chia seeds } \\
\text { - salvia hispanica } \\
(6,2 \%) \text {, natural extract } \\
\text { from hibiscus flowers }\end{array}$ & $\begin{array}{l}\text { Plant bar "Firecrac- } \\
\text { ker": dates, raspber- } \\
\text { ries, mulberry, cashew } \\
\text { nuts, Brazil nuts, chia } \\
\text { seeds, spirulina }\end{array}$ & $\begin{array}{l}\text { PowerWaters: mineral } \\
\text { water, organic caffeine }\end{array}$ \\
\hline $\begin{array}{l}\text { Nutritional values of } \\
\text { an example product } \\
\text { from the product } \\
\text { category }\end{array}$ & \begin{tabular}{|} 
Chias pomegranate- \\
-hibiscus, \\
1 portion of $200 \mathrm{ml}$. \\
Calorific value: 532 \\
kJ/128 kcal \\
Fats: $4.7 \mathrm{~g}$ \\
Carbohydrates: $15 \mathrm{~g}$ \\
(including sugar: $14 \mathrm{~g}$ ) \\
Protein: $3.5 \mathrm{~g}$ \\
No added sugar
\end{tabular} & $\begin{array}{c}\text { Plant bar "Firecrac- } \\
\text { ker", } \\
1 \text { bar } 69 \mathrm{~g} . \\
\text { Calorific value: } \\
1126 \mathrm{~kJ} / 269 \mathrm{kcal} \\
\text { Fats: } 8.2 \mathrm{~g} \\
\text { Carbohydrates: } 45.3 \mathrm{~g} \\
\text { (including sugar: } 31.7 \\
\text { g) } \\
\text { Protein: } 7.5 \mathrm{~g} \\
\text { No added sugar } \\
\end{array}$ & $\begin{array}{l}\text { PowerWaters, } 500 \mathrm{ml} . \\
\text { Calorific value: } \\
0 \mathrm{~kJ} / 0 \mathrm{kcal} \\
\text { Fats: } 0 \mathrm{~g} \\
\text { Carbohydrates: } 0 \mathrm{~g} \\
\text { (including sugar: } 0 \mathrm{~g} \text { ) } \\
\text { Protein: } 0 \mathrm{~g} \\
\text { No added sugar }\end{array}$ \\
\hline Website & www.chias.eu & www.zmianyzmiany.pl & $\begin{array}{l}\text { www.powerwaters. } \\
\text { com }\end{array}$ \\
\hline Instagram profile & @chias_eu & @zmianyzmiany & @powerwaters \\
\hline
\end{tabular}

Source: author' own research. 
TABLE 4. Analysis of Instagram profiles for the three brands: Chias, ZmianyZmiany, PowerWaters

\begin{tabular}{|c|c|c|c|}
\hline Specification & Chias & ZmianyZmiany & PowerWaters \\
\hline Number of all posts & 165 & 253 & 620 \\
\hline Number of all followers & 6,995 & 7,138 & 9,851 \\
\hline Number of profiles followed & 933 & 478 & 2,258 \\
\hline Total number of likes & 65,039 & 62,458 & 97,671 \\
\hline Total number of comments & 2,911 & 2,234 & 3,300 \\
\hline Average number of likes/posts & 394.2 & 246.9 & 157.5 \\
\hline $\begin{array}{l}\text { Average number of comments/ } \\
\text { /posts }\end{array}$ & 17.6 & 8.8 & 5.3 \\
\hline Date of first post published & 07.03 .2016 & 08.09 .2014 & 15.10 .2015 \\
\hline Frequency of posts published* & 0.4 a day & 0.23 a day & 1.17 a day \\
\hline $\begin{array}{l}\text { Ratio of the number of posts } \\
\text { containing the product to the } \\
\text { number of all posts }\end{array}$ & $96.36 \%$ & $91.7 \%$ & $87 \%$ \\
\hline $\begin{array}{l}\text { Ratio of the number of photos } \\
\text { reposted to the number of all } \\
\text { posts }\end{array}$ & $73.94 \%$ & $39.5 \%$ & $39.1 \%$ \\
\hline $\begin{array}{l}\text { Number of posts of other In- } \\
\text { stagram users tagged with the } \\
\text { profile } \\
\text { @chias_eu/@zmianyzmiany/ } \\
\text { @@powerwaters }\end{array}$ & 1055 & 810 & 975 \\
\hline $\begin{array}{l}\text { Hashtags generating greatest } \\
\text { interaction }\end{array}$ & $\begin{array}{c}\text { \#chias } \\
\text { \#nasionachias (chia } \\
\text { seeds) } \\
\text { \#zdrowo (healthy) }\end{array}$ & $\begin{array}{l}\text { \#zmianyzmiany } \\
\text { \#baton (bar) } \\
\text { \#vegan }\end{array}$ & $\begin{array}{c}\text { \#powerwaters } \\
\text { \#zdrowyenergetyk } \\
\text { (healthy energy } \\
\text { drink) } \\
\text { \#organic }\end{array}$ \\
\hline $\begin{array}{l}\text { Best time to trigger the enga- } \\
\text { gement of followers }\end{array}$ & $\begin{array}{l}\text { Monday } \\
10.00-11.00 \\
\text { Tuesday } \\
09.00-10.00\end{array}$ & $\begin{array}{l}\text { No time stands out } \\
\text { in a significant way, } \\
\text { impossible to deter- } \\
\text { mine a best time }\end{array}$ & $\begin{array}{c}\text { Friday } \\
16.00-17.00 \\
\text { Thursday } \\
12.00-13.00\end{array}$ \\
\hline $\begin{array}{l}\text { Use of additional Instagram } \\
\text { features }\end{array}$ & $\begin{array}{l}\text { Live story, sponso- } \\
\text { red posts }\end{array}$ & No such use & Sponsored posts \\
\hline Use of additional software & $\begin{array}{l}\text { Iconosquare, } \\
\text { Brand24, Google } \\
\text { Analytics }\end{array}$ & No such use & No information \\
\hline
\end{tabular}

If not stated otherwise, the data refers to the time between the first publication of a photo on the website and 31.03.2017* data for $29.01-30.03 .2017$

Source: authors' own research on the basis of an analysis of the profiles and the data obtained with Instagram Analytics for Business (www.minter.io) and Instagram User Report (www.simplymeasured.com). 
people. (...) The number of potential recipients who receive a given piece of information from a single user - infected with the information, as it were - is significant" [Śliwińska and Pacut 2011]. The mere ownership of an Instagram profile does not make one immediately successful. The key contributor is active administration of the profile understood as interaction with users (which includes liking photos posted by followers, responding to comments, publishing posts systematically). The PowerWaters brand did the best job in this respect, with a daily average of 1.17 posts in 60 days within the examined period, while for@zmianyzmiany the figure was as low as 0.23 post a day.

If we analyse the day of the week and the time at which specific profiles post their content, it is possible to specify time periods when publishing posts is the most efficient - published in that time, a photo or a video receives the most comprehensive response. The prime time for Chias is Monday between 10 and 11 a.m., for PowerWaters it is Friday between 4 and 5 p.m. These time periods can be referred to the producers' chosen methods of promoting and positioning their respective products. The producer advertises Chias as a healthy snack, for example at work between breakfast and lunch. Researchers of time management claim that on Mondays at around 10 a.m. there is a decline in the efficiency of work in offices - having completed their most urgent task for now, workers grab a snack and visit social networking websites, quite in keeping with the business idea of the Chias brand. As for Fridays between 4 and 5 p.m., for most people this is already free time after work and they can spend it by going jogging, visiting a fitness club or doing crossfit exercises - all of these activities favour the consumption of PowerWaters, which positions itself as a healthy energy drink. The above recommendations are applicable and ought to be used in order to maximise the efficiency of Instagram business activity.

In order to verify the Instagram profiles in question more accurately, the authors of the present study conducted in-depth interviews with experts, i.e. the representatives of the companies who are responsible for their presence and activity on social networking websites (Chias Brothers Europe Ltd., ZmianyZmiany (civil law partnership), Emptio Ltd.). The owner of the Chias brand and the manager of the brands belonging to the ZmianyZmiany group both admit that Instagram is their main tool used for the development of brand awareness among potential clients. Both companies employ the following strategies in order to manage their Instagram profiles:

- publishing posts at equal intervals,

- presenting products in different contexts, not only during product photo sessions,

- reposting photos of other users and barter exchange,

- liking photos of potential clients.

As a matter of fact, it is the above mentioned barter exchange that looms as the key to success in the case of managing Instagram profiles devoted to superfood products. The legal definition of barter exchange is that it consists in cashless exchange of goods or services. Regarding the analysed businesses, however, it assumes the form of publishing photos within a user's own social media channel in return for goods received free of charge. Krzysztof Pahl, deputy chairman of Emptio, a trade company dealing in the so-called fast-moving consumer goods (FMCG in short) within the superfood category mentioned that it is not uncommon for the rate of return from this sort of barter exchange with Instagram users to be $1: 20$ - one item sent to a given person results in 20 followers of that person ordering the product. As regards the so-called digital influencers - users 
with thousands of followers - that rate is likely to skyrocket. To confirm this, let's quote a representative of the Chias brand: "We send our products to influencers when there is some important event taking place, for example launching a new product. (...) We try to establish a good rapport with them. We post comments to their photos and like them. This makes influencers feel we care about them. We do our best to react - if we can see a famous person drinking anything unhealthy, like Red Bull, we offer them to try our natural energy drinks and we send them a packet with our products. (...) The rule of reciprocity usually kicks in at this stage - people want to return the favour and they post their own photo with our product to their own profile or as an insta story." Barter exchange with respect to superfood products is a phenomenon that has been developing dynamically and in the future it is going to be put to common use, just like it happens in the case of the fashion industry.

\section{CONCLUSION}

In the context of all the marketing strategies available today, the intensifying presence of enterprises in social media is more and more visible. It is strictly related with the changing behavioural patterns in buyers, who spend more and more of their time on social networking websites in ever greater numbers. Using mobile devices to visit such websites is particularly popular and this is where Instagram thrives, with its big photographs and easy interaction patterns providing the necessary functionality when mobile phones and tablets are in use. By actively communicating in this channel, an enterprise has a direct impact on their consumers' online shopping decisions. So far the analysis of the activity of brands dealing in superfood products has indicated that producers of such goods have been using the tool correctly, although in fact attitudes vary noticeably in terms of the actual number of posts as well as their frequency. A good example here is the producer of the Chias drink, who pays close attention to their interaction with followers - potential buyers of their products. This is attested to by for instance a significant number of posts of Instagram users in which @ chias_eu is tagged. It also proves the importance of adopting smartly designed communications policies for the sake of social media, particularly with respect to new channels of communication such as Instagram in the case of industries marketing products with a number of characteristic features.

Recommendations for small and medium-sized company owners that follow from the conducted analysis include elements such as the use of photos posted by brand supporters and influencers - or in fact, a number of things defined by the umbrella term of UGC, or user-generated content. For the grand majority of the followers of an Instagram profile what really matters is not the source of a post but its content. However, posts published by people who are not affiliated with a given enterprise often achieve higher levels of professionalism and enjoy greater trust of followers and better engagement rates than any FGC (firm-generated content). It is also advisable to keep track of the behaviour of followers by identifying specific days and times when followers are eager to interact with a given Instagram profile. The most efficient communications method is posting at times when followers are most likely to be active. Another thing to take note of is that barter exchange - posts in return for products free of charge - is relatively profitable in terms of 
the ratio between a company's costs and income. The thing that stands out, however, is that communication needs to be systematic because, regardless of the product they might be interested in, followers expect regularity of posts and interaction between the brand and its customers. It certainly enhances the efficiency of the strategy for a given brand's online presence.

Due to the limited data examined for the sake of the present study, a more comprehensive look at the issue would certainly be useful, one that would involve points of view from other lines of business. It would also do no harm to expand the analysis with Instagram data relating to sales figures (e.g. tagging products in posts, the use of the "Shop Now" button) as well as to analyse similar activity on other social networking websites.

\section{REFERENCES}

BAREFOOT D., SZABO J., 2011. Znajomi na wagę złota. Podstawy marketingu w mediach społecznościowych (Friends with Benefits. A Social Media Marketing Handbook) [in Polish], Wolters Kluwer Polska, Warszawa.

EKIERT K., DOCHNAL M., 2015. Superfoods - idealne uzupełnienie diety czy zbędny dodatek? (Superfoods - perfect diet supplement or unnecessary addition?) [in Polish], Pielęgniarstwo i Zdrowie Publiczne, Wrocław Medical University, Wrocław.

ERKAN I., 2015. Electronic Word of Mouth on Instagram: Customers' Engagements with Brands in Different Sectors, International Journal of Management, Accounting and Economics $2,12,1435-1444$.

GARIFOVA L F., 2016. Realization Of Small Businesses Economic Interests On Instagram, Journal of Economics and Economic Education Research 17, Special Issue.

GUMIŃSKA I., 2017. Social selling. Nowy rozdział w sprzedaży (Social selling. A new chapter in sales) [in Polish], Business Life Poland, MajerMedia Publishing House, 6, 60-65.

HASSAN A., 2014. Do brands targeting women use instamarketing differently: a content analysis, Marketing Management Association Spring 2014 Proceedings, Chicago.

INSTAGRAM 2016, Shopping Coming to Instagram, retrived from https://business.instagram. com/blog/shopping-on-instagram [accessed: 19.03.2017].

INSTAGRAM 2017a, A Better Shopping Experience on Instagram, retrived from https://business. instagram.com/blog/a-better-shopping-experience-on-instagram [accessed: 23.03.2017].

INSTAGRAM 2017b, Welcoming 1 Million Advertisers, retrived from https://business.instagram. $\mathrm{com} / \mathrm{blog} /$ welcoming-1-million-advertisers, [accessed: 23.03.2017].

KARWAT Z., 2016. Media społecznościowe w procesie sprzedaży (Social media in the sales process) [in Polish], Nowa Sprzedaż, Grupa Marketer, 1(1), 32-36.

KOTLER P., KELLER K.L., 2012. Marketing, REBIS Ltd. Publishing House, Poznań.

KUMAR A., BEZAWADA R., RISHIKA R., JANAKIRAMAN R., KANNAN P. K., 2016. From Social to Sale: The Effects of Firm-Generated Content in Social Media on Customer Behavior, Journal of Marketing 80, 7-25.

MOMANY M., ALSHBOUL A., 2016, Social media marketing: utilizing social media to advance brand awareness and increase online sales, International Journal of Business, Marketing, and Decision Sciences 9, 1, 33-54.

Petrolvenience Raport, 2016, Nielsen, Warszawa. 
PricewaterhouseCoopers, 2016, They Say They Want a Revolution: Total Retail 2016, retrived from https://www.pwc.com/gx/en/retail-consumer/publications/assets/total-retail-globalreport.pdf [accessed: 23.03.2017].

ŚLIWIŃSKA K., PACUT M., 2011, Narzędzia i techniki komunikacji marketingowej XXI wieku (Tools and Techniques of Marketing Communications in $21^{\text {st }}$ Century) [in Polish], Wolters Kluwer Polska, Warszawa.

We are social, 2017, Digital in 2017 Global Overview, retrived from http://wearesocial.com/ blog/2017/01/digital-in-2017-global-overview [accessed: 19.03.2017].

WOLFE D., 2015, Superżywność. Jedzenie i medycyna przyszłości (Superfood. Food and medicine of the future) [in Polish], Vivante Publishing House, Białystok.

Summary. Social media, Instagram included, are more and more often used by enterprises to promote their own products. Year by year there has been an increase in the rate of the use of the analysed channels of marketing, which seem to be one of the most basic forms of spreading information about their products for enterprises active in the field of superfood products. Superfoods are products containing elements characterised by a wealth of nutritional values, e.g. chia seeds or goji berries. The article presents a short characteristic of social media and defines the eponymous superfood category. The research section of the publication analyses the Instagram activity of three Polish producers of food containing superfood elements, namely Chias - a snack producer, ZmianyZmiany - a producer of plant bars, and PowerWaters - a producer of water with caffeine. The current state of affairs with respect to Instagram profiles of the three discussed brands are studied comprehensively and several applicable recommendations are presented. The research also touches upon the issue of improving customer engagement levels as well as the issue of barter exchange as a way to increase sales and brand awareness in the virtual world.

Key words: superfood, instagram, online communication, social selling

JEL: M31, L81

Corresponding author: Anna Roth, Poznań University of Economics and Business, Faculty of Management, Department of Commerce and Marketing, al. Niepodległości 10, 61-875 Poznań, Poland, e-mail: anna.roth@ue.poznan.pl; Tomasz Zawadzki, Poznań University of Economics and Business, Faculty of Management, Department of Commerce and Marketing, al. Niepodległości 10, 61-875 Poznań, e-mail: tomasz.zawadzki@ue.poznan.pl

Received: 03.04 .2017

Accepted: 01.09 .2017 
